\title{
Induction of defence related enzymes and biocontrol efficacy of Tricho- derma harzianum in tomato plants infected with Fusarium oxysporum and Fusarium solani
}

\author{
Tavga Sulaiman RASHID ${ }^{1}$, Sirwa Anwar QADIR ${ }^{1}$, Hayman Kakakhan AWLA ${ }^{2,3}$
}

Received April 18, 2020; accepted January 27, 2021. Delo je prispelo 18. aprila 2020, sprejeto 27. januarja 2021.

Induction of defence related enzymes and biocontrol efficacy of Trichoderma harzianum in tomato plants infected with $\mathrm{Fu}$ sarium oxysporum and Fusarium solani

Abstract: Fusarium wilt of tomato plants caused by $\mathrm{Fu}$ sarium oxysporum Schlecht. emend. Snyder \& Hansen and Fusarium solani (Mart.) Sacc. are serious problem limiting tomato production worldwide. Biological control has emerged as one of the most promising alternatives to chemical fungicides. The biological control capability of a T. harzianum isolate against $F$. solani and F. oxysporum has been investigated. It inhibited colony growth of two Fusarium species by more than $80 \%$ in dual culture tests. Results of greenhouse experiments revealed that disease severity in the tomato plants co-inoculated with T. harzianum was significantly lower than plants only infected with the Fusarium pathogens. Tomato plants inoculated with the antagonistic T. harzianum isolate, showed enhanced peroxidase and polyphenol oxidase activities in greenhouse experiments and increased resistance to F. solani and F. oxysporum. The T. harzianum isolate indirectly affected the Fusarium pathogens by enhancing plant defence.

Key words: fungal pathogens; antagonistic fungus; peroxidase; polyphenol oxidase; plant growth and biological control
Vzpodbuditev aktivnosti encimov povezanih $\mathrm{z}$ obrambo in učinkovitost biokontrole $\mathrm{z}$ glivo Trichoderma harzianum Rifai v paradižniku okuženem z glivama Fusarium oxysporum Schlecht. emend. Snyder \& Hansen in Fusarium solani (Mart.) Sacc.

Izvleček: Fuzarijska venenja paradižnika, ki jih povzročata glivi Fusarium oxysporum Schlecht. emend. Snyder \& Hansen in Fusarium solani (Mart.) Sacc. so resen problem, ki omejuje svetovno pridelavo paradižnika. Biološka kontrola se je pokazala kot najbolj obetajoča alternativa kemičnim fungicidom. $\mathrm{V}$ raziskavi je bila preučevana sposobnost biološkega uravnavanja gliv F. solani in F. oxysporum z izolati glive Trichoderma harzianum. Izolati so zavrli rast kolonij obeh vrst iz rodu Fusarium za več kot $80 \%$ v preiskusih dvojnih kultur. Izsledki iz poskusov $\mathrm{v}$ rastlinjaku so pokazali, da je bila obolelost pradižnika značilno manjša, če je bil ta inokuliran hkrati z obema patogenima glivama iz rodu Fusarium in $\mathrm{z}$ glivo T. harzianum. Ratline paradižnika, ki so bile inokulirane $z$ izolati antagonistične glive $T$. harzianum so imele $\mathrm{v}$ poskusih $\mathrm{v}$ rastlinjaku povečani aktivnosti peroksidaze in polifenol oksidaze ter povečano odpornost proti patogenima glivama F. solani in F. oxysporum. Izolati iz glive T. harzianum so neposredno vplivali na patogena iz rodu Fusarium s povečanjem obrambe rastlin.

Ključne besede: paradižnik; patogene glive; antagonistične glive; rast in biološka kontrola; peroksidaza; polifenol oksidaza

1 Salahaddin University, College of Agricultural Engineering Sciences, Department of Plant Protection, Erbil, Iraq

2 Erbil Polytechnic University, Khabat Technical Institute, Department of Plant Protection, Iraq

3 Corresponding author, e-mail: hayman.awla@epu.edu.iq 


\section{INTRODUCTION}

Tomato plants can be attacked by different soilborne fungi, which cause severe diseases such as wilt and root rot (Morsy et al., 2009). Fusarium species are the most common pathogens, which can live in organic materials and nearly all soil types (Boyaci et al., 2010). They can attack the vascular system in infected plants, block water transport through xylem by inducing vessel plugging, leading to foliage wilt and finally plant death (Portal et al., 2018; Malandrakis et al., 2018).

The attempts to minimise the use of fungicides make it necessary to develop economical and effective methods to obtain biopesticides that are based on endogenous microorganisms (de los Santos-Villalobos et al., 2012). Trichoderma (Hypocreales) accommodates various soil-borne and pathogen-antagonistic species (Verma et al., 2007). Trichoderma harzianum is well known for its antagonistic effect on pathogenic fungi. It is the most potent biocontrol agent that inhibits the growth of Fusarium species. Mechanisms of biocontrol agent are based on antifungal metabolites, mycoparasitism, competition for nutrients and induced resistance (Perello et al., 2003; Silva et al., 2019).

Moreover, an increased activity of polyphenol oxidase and peroxidase in response to the infection by the pathogen is considered to play an active role in contributing to disease resistance in certain plant hosts (Vidhyasekaran, 2004). Pradeep and Jambhale (2002) and Vidhyasekaran (2004) observed that plants show increased activities of polyphenol oxidases and peroxidases in response to pathogen infections and the ability of a plant to resist disease. The present study investigated the effectiveness of T. harzianum to induce systemic resistance against Fusarium solani and Fusarium oxysporum when infecting tomato plants.

\section{MATERIALS AND METHODS}

\subsection{ANTAGONISTIC ACTIVITY}

Trichoderma harzianum isolate UPM40 was obtained from the plant protection department, faculty of agriculture, University Putra Malaysia and was evaluated in vitro for its antagonistic activity against two Fusarium isolates in dual culture method (Rahman et al., 2009). DNA barcoding strategies based on ITS sequences were used to identify one of the Fusarium as a member of the F. solani (KM039055) and the other as a member of the $F$. oxysporum species complex (KM039054) (from previous study Rashid et al., 2016). Isolate UPM40 was identified as a member of Trichoderma harzianum species complex on the basis of morphological characters. Discs of $6 \mathrm{~mm}$ diameter of the antagonist and pathogens were cut from the edge of actively growing colonies on potato dextrose agar (PDA Difco ${ }^{\mathrm{TM}}$ ) and placed at opposite sides $(4.5 \mathrm{~cm}$ from each other) on PDA plates. Each antagonist/pathogen combination was set up in triplicates. The plates were incubated at $24 \pm 2{ }^{\circ} \mathrm{C}$. The antagonistic effect of the test fungus was estimated by measuring their radial growth in comparison to control plates using the following formula: $\mathrm{I}=[(\mathrm{C}-\mathrm{T}) / \mathrm{C}] \mathrm{X} 100$ where: $\mathrm{I}=\%$ of inhibition in the mycelia growth, $\mathrm{C}=$ the growth of pathogens in control plates and $\mathrm{T}=$ the growth of pathogens in the dual culture plates.

\subsection{SOIL PREPARATION AND EXPERIMENTAL DESIGN}

Soil comprising clay, sand and organic matter (1:1:1 $\mathrm{v}: \mathrm{v})$ from Erbil Governorate ( $\mathrm{pH}$ 5.5-6) was air dried and sieved $(5 \mathrm{~mm})$, sterilised twice in an autoclave at $121^{\circ} \mathrm{C}$ for one hour and allowed to cool for 24 hours before use.

The tomato ('Baccarat 322') seeds were surface disinfected by soaking them in $95 \%$ ethanol for 10 seconds, followed by $3 \%$ sodium hypochlorite for 1 minute and then washed 6 times with sterile distilled water. Two tomato seeds were planted per plastic cell in seedling growing trays. The seedlings were trimmed down to one seedling per cell after two weeks. The one-month-old tomato plants were then moved to clean pots (two plants/ pot). On a daily basis, these plants were watered with tap water. The independently repeated experiment was conducted in a completely randomised design.

\subsection{IN VIVO TEST}

A Neubauer haemocytometer was used to adjust the T. harzianum spore concentration to $2 \times 10^{5} \mathrm{spore} / \mathrm{ml}$ (working solution). The soil with one-month-old tomato plants was drenched with $100 \mathrm{ml}$ of working solution (Mahato et al., 2018). After 24 hours, the same amount of $2 \times 10^{5}$ spore/ml pathogen suspension was added to the soil per pot.

\subsubsection{Chlorophyll content measurement}

The chlorophyll content was measured in ten repetitions per leaf (5 plants per treatment) with a CL-01 Chlorophyll Content Metre after 30 days of inoculation. This device measured the relative chlorophyll content via dual wavelength optical observance (620 and $940 \mathrm{~nm}$ ). 


\subsubsection{Sample collection for the biochemical analysis}

The roots of the treated and untreated tomato plants were collected 10, 20 and 30 days after the treatment application; they were washed in running tap water and stored in a deep freezer $\left(-80^{\circ} \mathrm{C}\right)$ until they were used for the biochemical analysis.

\subsubsection{Total protein content measurement}

Protein extracts were generated from roots and protein concentrations were determined using the method described by Arora and Wisniewski (1994), of which the latter was based on Bradford assays.

\subsubsection{Quantification of polyphenol oxidase (PPO) ac- tivity}

The reaction mixture consisted of $0.5 \mathrm{ml}$ of the enzyme extract and $2.3 \mathrm{ml}$ of $0.1 \mathrm{M}$ phosphate buffer $(\mathrm{pH}$ $=6.1$ ). Both were mixed in a cuvette and adjusted to the zero absorbance of a spectrophotometer (Mahadevan and Sridhar, 1982). Catechol solution $(0.1 \mathrm{M}, 0.2 \mathrm{ml})$ was added and the reactants were quickly mixed. The enzyme activity, measured as the change in absorbance per minute ( $\ddot{\mathrm{A}} \mathrm{A} / \mathrm{min})$ at $400 \mathrm{çm}$, was measured immediately after the addition of the catechol solution.

\subsubsection{Quantification of peroxidase (PO) activity}

Peroxidase activity was determined according to Sreedevi et al. (2011). The peroxidase enzyme activity was determined from the roots of the un-inoculated and inoculated tomato plants. About $0.5 \mathrm{~g}$ of freshly harvested material was ground in a pre-chilled mortar with $20 \mathrm{ml}$ of $0.1 \mathrm{M}$ cold ice phosphate buffer ( $\mathrm{pH} 7.1$ ) and centrifuged at $2000 \mathrm{rpm}$ for 10 minutes. The supernatant was made up to $25 \mathrm{ml}$ and used for the assay. Freshly prepared pyrogallol $(0.2 \mathrm{M})$ reagent $(0.1 \mathrm{ml}), 1.0 \mathrm{ml}$ of the enzyme extract, and $1.4 \mathrm{ml}$ of the $0.1 \mathrm{M}$ phosphate buffer $(\mathrm{pH}, 7.1)$ were mixed in a cuvette, and the mixture was immediately adjusted to the zero absorbance of a spectrophotometer. The $\mathrm{H}_{2} \mathrm{O}_{2}$ solution $(0.5 \mathrm{ml}$ of $0.01 \mathrm{M})$ was added to it, and the content was mixed by inverting the cuvette. The enzyme activity was recorded according to the changes in absorbance per minute $(\ddot{\mathrm{A} A} / \mathrm{min} / \mathrm{a})$ at $430 \mathrm{~cm}$.

\section{RESULTS AND DISCUSSION}

\subsection{ANTAGONISTIC ACTIVITY}

The results indicated that Trichoderma harzianum (T. h) reduced the radial growth of F. solani (F. s) colony by $82.31 \%$ and F. oxysporum (F. o) by $80.25 \%$.

\subsection{IN VIVO EXPERIMENT}

Trichoderma treated plants showed increased plant height, fresh shoot mass and root dry mass when coinoculated with F. o $(20.6 \mathrm{~cm}, 0.79 \mathrm{~g}$ and $0.15 \mathrm{~g})$ or F. $\mathrm{s}$ $(27 \mathrm{~cm}, 0.66 \mathrm{~g}$ and $0.17 \mathrm{~g})$. Plants treated only with F. o had $10.17 \mathrm{~cm}$ and $14.00 \mathrm{~cm}$ height $(0.31 \mathrm{~g})$ shoot mass and $(0.06 \mathrm{~g})$ root mass. In addition, plants inoculated only with $\mathrm{T}$. $\mathrm{h}$ showed the highest mean values for plant height, shoot dry mass and root dry mass $(32.33 \mathrm{~cm}$, $1.02 \mathrm{~g}$ and $0.18 \mathrm{~g}$ ) compared to other treatments and control plants (Table 1). The increased growth response caused by Trichoderma isolate may be due to the modification of the rooting system (Chao et al., 1986). The results further indicate that $T$. harzianum had a significant role in reducing disease incidence. Therefore, the results of the study are similar to the findings of Abd- El-Khair et al. (2011), Otadoh et al. (2011) and Alwathnani et al. (2012).

Table 1: Effect of T. harzianum, F. oxysporum and F. solani on shoot height (cm), shoot and root dry mass (g) on tomato plants

\begin{tabular}{llll}
\hline Treatments & Shoot height $(\mathrm{cm})$ & Shoot dry mass $(\mathrm{g})$ & Root dry mass $(\mathrm{g})$ \\
\hline Control & $22.67 \mathrm{a}$ & $0.76 \mathrm{a}$ & $0.14 \mathrm{a}$ \\
T. h & $32.33 \mathrm{~b}$ & $1.02 \mathrm{c}$ & $0.18 \mathrm{~b}$ \\
F. $\mathrm{c}$ & $10.17 \mathrm{c}$ & $0.17 \mathrm{~d}$ & $0.06 \mathrm{c}$ \\
F. $\mathrm{s}$ & $14.00 \mathrm{~d}$ & $0.31 \mathrm{e}$ & $0.06 \mathrm{c}$ \\
T. $\mathrm{h}+$ F. o & $20.67 \mathrm{e}$ & $0.79 \mathrm{a}$ & $0.15 \mathrm{~d}$ \\
T. $\mathrm{h}+$ F. s & $27.00 \mathrm{f}$ & $0.66 \mathrm{~b}$ & $0.17 \mathrm{be}$ \\
\hline
\end{tabular}

C: control; F. o: F. oxysporum; F. s: F. solani and T. h: T. harzianum. 


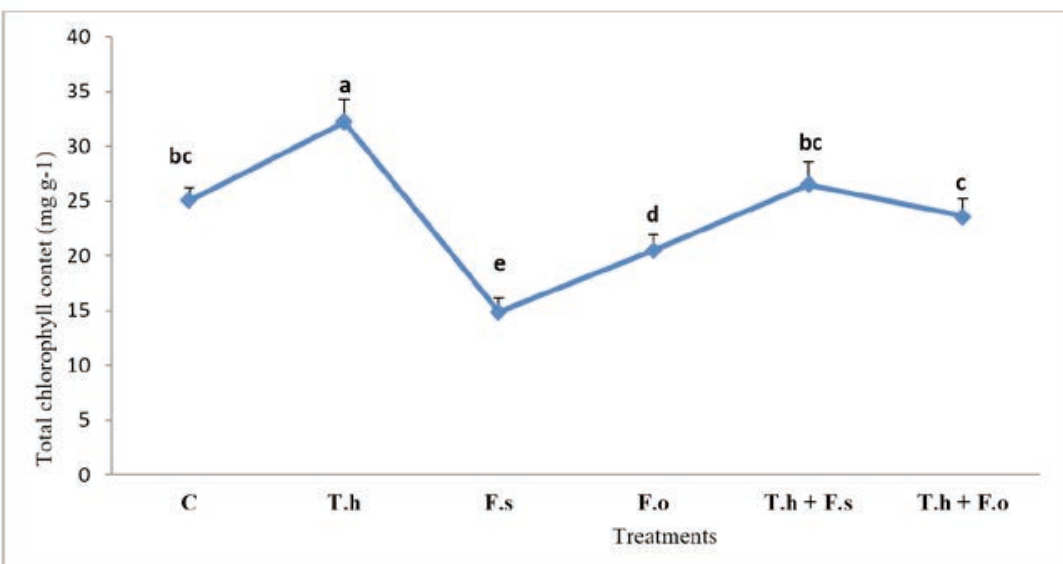

Figure 1: Effect of T. harzianum on chlorophyll content of the tomato plants inoculated with F. oxysporum and F. solani.

One of the important physiological indicators is the photosynthesis rate, which is related to the chlorophyll content in plant leaves in normal conditions. In the present study, the chlorophyll content was found to increase significantly in all plants treated with $\mathrm{T}$. h compared to those inoculated with F. s or F. o. The chlorophyll content also significantly went up in plants treated with $\mathrm{T}$. $\mathrm{h}+\mathrm{F} . \mathrm{s}$ (26.5) or T. h + F. o (23.5) in comparison to the F. o and F. s only (14.86 and 20.5) inoculated plants (Figure 1). Previous studies have claimed that applying biocontrol agents to infected plants increases mineral levels [(nitrogen $(\mathrm{N})$, phosphorous $(\mathrm{P})$, potassium $(\mathrm{K})$ and magnesium $(\mathrm{Mg})]$, chlorophyll biosynthesis and photosynthetic activity (Henry et al., 2009; Morsy et al., 2009; Alwathnani et al., 2012).

The total soluble protein content significantly decreased in tomato plants: F. s $(0.082,0.076$ and 0.075$)$ and F. o $(0.084,0.074$ and 0.072$)$ after 10, 20 and 30 days, respectively (Figure 2). The significant decrease in the protein content in the tomato tissues as a result of the pathogen infection may be due to certain activities related to a hypersensitive response (Chandra and Bhatt, 1998). Trichoderma harzianum also increased the total protein content in the infected tomato plants $(\mathrm{T} . \mathrm{h}+\mathrm{F}$. $\mathrm{s}$ and $\mathrm{T} . \mathrm{h}+\mathrm{F} . \mathrm{o})$. The defence reaction occurs due to an accumulation of pathogenesis-related (PR) proteins such as chitinase, phenylalanine ammonia lyase and peroxidase (Kloepper et al., 1992). This has also been previously reported by Houssien et al. (2010).

Tables 2 and 3, show that the activity of peroxidase and polyphenol oxidase, increased significantly compared to the controls. The activity increased during the treatment period from day 10 to day 30. Also Fusarium species are able to produce metabolites, which play a vital role in tissue browning due to their ability to oxidise phenols to quinones (Ramadoss, 1991). Except the tomato plant inoculated only with the antagonistic T. harzianum, there was an increase in the activity of the polyphenol ox-

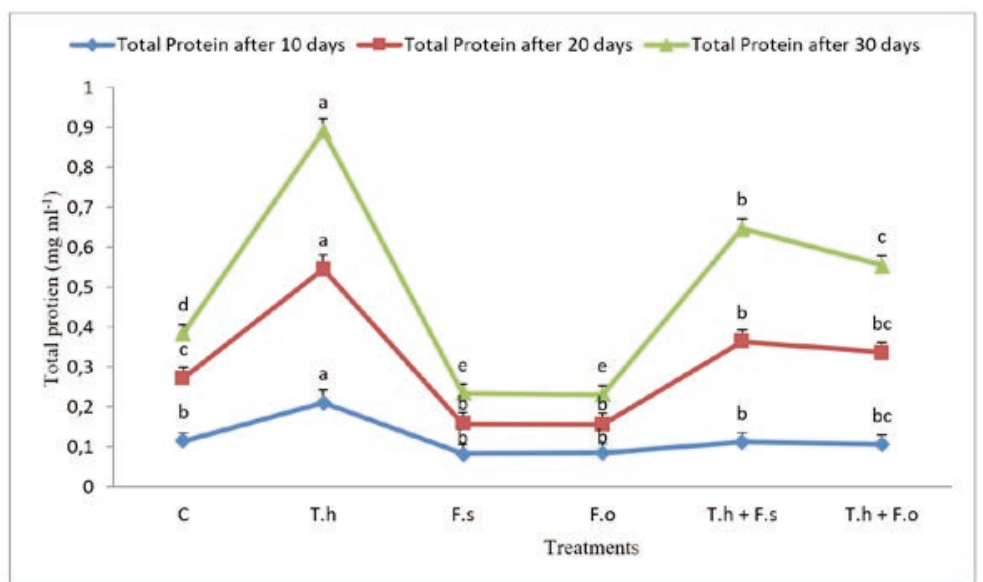

Figure 2: Effect of T. harzianum on the total protein content $\left(\mathrm{mg} \mathrm{g}^{-1}\right)$ of the tomato plants inoculated with F. oxysporum and F. solani.. 
Table 2: Effect of Trichoderma harzianum on the peroxidase activity of the tomato plants inoculated with F. oxysporum and F. solani

\begin{tabular}{llll}
\hline & \multicolumn{2}{l}{ Peroxidase activity min $^{-1}$ fresh mass of tomato leaves } & After 30 days \\
\cline { 2 - 4 } Treatments & After 10 days & After 20 days & $0.15 \mathrm{a}$ \\
\hline Control & $0.18 \mathrm{a}$ & $0.17 \mathrm{a}$ & $0.36 \mathrm{~b}$ \\
T.h & $0.16 \mathrm{a}$ & $0.43 \mathrm{~b}$ & $0.59 \mathrm{c}$ \\
F.o & $0.25 \mathrm{~b}$ & $0.34 \mathrm{c}$ & $0.62 \mathrm{~cd}$ \\
F.s & $0.27 \mathrm{bc}$ & $0.47 \mathrm{~cd}$ & $1.87 \mathrm{f}$ \\
T.h+ F.o & $0.27 \mathrm{bc}$ & $1.20 \mathrm{f}$ & $1.95 \mathrm{f}$ \\
T.h+ F.s & $0.29 \mathrm{~cd}$ & $1.29 \mathrm{fg}$ &
\end{tabular}

Table 3: Effect of T. harzianum on the polyphenol oxidase activity of the tomato plants inoculated with F. oxysporum and F. solani

\begin{tabular}{llll}
\hline & \multicolumn{2}{l}{ Polyphenol oxidase activity min $^{-1}$ fresh mass of tomato leaves } \\
\cline { 2 - 4 } Treatments & After 10 days & After 20 days & After 30 days \\
\hline Control & $0.16 \mathrm{a}$ & $0.18 \mathrm{a}$ & $0.13 \mathrm{a}$ \\
T.h & $0.17 \mathrm{a}$ & $0.31 \mathrm{~b}$ & $0.17 \mathrm{a}$ \\
F.o & $0.22 \mathrm{~b}$ & $0.35 \mathrm{ab}$ & $0.69 \mathrm{~b}$ \\
F.s & $0.21 \mathrm{~b}$ & $0.39 \mathrm{bc}$ & $0.75 \mathrm{bc}$ \\
T.h+ F.o & $0.29 \mathrm{c}$ & $1.28 \mathrm{~d}$ & $2.71 \mathrm{~d}$ \\
T.h+ F.s & $0.27 \mathrm{c}$ & $1.29 \mathrm{~d}$ & $2.55 \mathrm{de}$ \\
\hline
\end{tabular}

idase and peroxidase up to the $20^{\text {th }}$ day. After this time, the activity decreased or remained stable. At the initial stage of infection, there is probability of the host plant to secrete more defence enzymes (Ojha et al., 2012). The activity increased gradually from the $20^{\text {th }}$ day up to the $30^{\text {th }}$ day in the plants infected with T. h. + F. o. and T. h. + F. s.. The highest activities for both treatments 1.87 and $1.95 \mathrm{~min}$ $\mathrm{g}^{-1}$ for fresh mass of peroxidase and 2.71 and $2.55 \mathrm{~min}^{-1}$ for fresh mass of polyphenol oxidase were recorded after the $30^{\text {th }}$ day of inoculation. This is the most likely related to the fact that in tomato plants, when inoculated with a pathogen and an antagonist, the host plant secretes more of the phenol oxidase enzyme for defence, but at the later stages of infection, the antagonist blocks the activity of the pathogen. Various antioxidant enzymes, such as peroxidases and polyphenol oxidases can participate in the reactive oxygen metabolism of the species during infection (Morkunas and Gmerek, 2007). Other researchers have observed increased activity in these enzymes in the host tissues in response to pathogenic infections (Abo-Elyousr et al., 2008, Christopher et al., 2010; Ojha et al., 2012).

\section{CONCLUSION}

The experiments demonstrated that the T. harzianum is effective and can induce systemic and localized resistance against Fusarium infection in terms of changes of the plants' polyphenol oxidase activity, peroxidase activity and the total phenolic content. These mechanisms help to develop resistance in tomato plants. The current study suggests using $T$. harzianum strain (UPM40) to manage Fusarium diseases in tomato plants.

\section{REFERENCES}

Abd-El-Khair H, Khalifa R K M, Haggag K H. (2010). Effect of Trichoderma species on damping off diseases incidence, some plant enzymes activity and nutritional status of bean plants. American Journal of Science, 6(9), 486-497.

Abo-Elyousr K A, Hashem M, Ali E H. (2009). Integrated control of cotton root rot disease by mixing fungal biocontrol agents and resistance inducers. Crop Protection, 28(4), 295-301. https://doi.org/10.1016/j.cropro.2008.11.004

Alwathnani H A, Perveen K, Tahmaz R, Alhaqbani S. (2012). Evaluation of biological control potential of locally isolated antagonist fungi against Fusarium oxysporum under in vitro and pot conditions. African Journal of Microbiology Research, 6(2), 312-319. https://doi.org/10.5897/AJMR11.1367

Arora R, Wisniewski M E. (1994). Cold acclimation in genetically related (sibling) deciduous and evergreen peach (Prunus persica [L.] Batsch)(II. A 60-kilodalton bark protein in cold-acclimated tissues of peach is heat stable and related to the dehydrin family of proteins). Plant Physiology, 105(1), 95-101. https://doi.org/10.1104/pp.105.1.95

Boyaci F, Unlu A, Abak K. (2010). August. Screening for resistance to Fusarium wilt of some cultivated eggplants and wild 
Solanum accessions. In XXVIII International Horticultural Congress on Science and Horticulture for People (IHC2010): International Symposium on New 935 (pp. 23-27). https:// doi.org/10.17660/ActaHortic.2012.935.2

Chandra A, Bhatt R K. (1998). Biochemical and physiological response to salicylic acid in relation to the systemic acquired resistance. Photosynthesis, 35, 255-258. https://doi. org/10.1023/A:1006966908357

Chao W l, Nelson E B, Harman G E, Hoch H C. (1986). Colonization of the rhizosphere by biological control agents applied to seeds. Phytopathology, 76, 60-65. https://doi.org/10.1094/ Phyto-76-60

Christopher D J, Raj T S, Rani S U, Udhayakumar R. (2010). Role of defense enzymes activity in tomato as induced by Trichoderma virens against Fusarium wilt caused by Fusarium oxysporum f sp. lycopersici. Journal of Biopesticides, 3(1), 158162.

de los Santos-Villalobos S, Barrera-Galicia G C, Miranda-Salcedo M A, Peña-Cabriales J J. (2012). Burkholderia cepacia XXVI siderophore with biocontrol capacity against Colletotrichum gloeosporioides. World Journal of Microbiology and Biotechnology, 28(8), 2615-2623. https://doi.org/10.1007/ s11274-012-1071-9

FAOSTAT (2017). Production - Crops - Area harvested/ Production quantity - Tomatoes - 2014, FAO Statistics online database, Food and Agriculture Organization, Rome, www. fao.org/faostat/en (accessed 22 Sept. 2017).

Henry A, Kleinman P J, Lynch J P. (2009). Phosphorus runoff from a phosphorus deficient soil under common bean (Phaseolus vulgaris L.) and soybean (Glycine max L.) genotypes with contrasting root architecture. Plant and Soil, 317(1-2), 1-16. https://doi.org/10.1007/s11104-008-9784-0

Herrera-Téllez V I, Cruz-Olmedo A K, Plasencia J, GavilanesRuíz M, Arce-Cervantes O, Hernández-León S, SaucedoGarcía M. (2019). The protective eEffect of Trichoderma asperellum on tomato plants against Fusarium oxysporum and Botrytis cinerea diseases involves inhibition of reactive oxygen species production. International Journal of Molecular Sciences, 20(8), 2007. https://doi.org/10.3390/ijms20082007

Houssien A A, Ahmed S M, Ismail A. A. (2010). Activation of tomato plant defense response against Fusarium wilt disease using Trichoderma harzianum and salicylic acid under greenhouse conditions. Research Journal of Agriculture and Biological Sciences, 6(3), 328-338.

Kloepper J W, Wei G, Tuzun S. (1992). Rhizosphere population dynamics and internal colonization of cucumber by plant growth-promoting rhizobacteria which induce systemic resistance to Colletotrichum orbiculare. In Biological control of plant diseases (pp. 185-191). Springer, Boston, MA. https:// doi.org/10.1007/978-1-4757-9468-7_24

Mahato S, Bhuju S, Shrestha J. (2018). Effect of Trichoderma viride as biofertilizer on growth and yield of wheat. Malays Journal of Sustainable Agriculture, 2(2), 1-5. https://doi. org/10.26480/mjsa.02.2018.01.05

Morkunas I, Gmerek J. (2007). The possible involvement of peroxidase in defense of yellow lupin embryos axes against Fusarium oxysporum. Journal of Plant Physiology, 164(6), 497-506. https://doi.org/10.1016/j.jplph.2005.11.005

Malandrakis A, Daskalaki E R, Skiada V, Papadopoulou K K,
Kavroulakis N. (2018). A Fusarium solani endophyte vs fungicides: Compatibility in a Fusarium oxysporum f. sp. radicislycopersici-tomato pathosystem. Fungal Biology, 122(12), 1215-1221. https://doi.org/10.1016/j.funbio.2018.10.003

Morsy E M, Abdel-Kawi K A, Khalil M N A. (2009). Efficiency of Trichoderma viride and Bacillus subtilis as biocontrol agents gainst Fusarium solani on tomato plants. Egyptian Journal of Phytopathology, 37, 47-57.

Ojha S, Chatterjee N. (2012). Induction of resistance in tomato plants against Fusarium oxysporum f. sp. lycopersici mediated through salicylic acid and Trichoderma harzianum. Journal of Plant Protection Research, 52(2), 220-225. https://doi. org/10.2478/v10045-012-0034-3

Otadoh J, Okoth S, Ochanda J, Kahindi J. (2010). Assessment of Trichoderma isolates for virulence efficacy on Fusarium oxysporum f. sp. phaseoli. Tropical and Subtropical Agroecosystems, 13(1), 99-107.

Perello A, Monaco C, Simon M R, Sisterna M, Dalbello G. (2003). Biocontrol efficacy of Trichoderma isolates for tar spot of wheat in Argentina. Crop Protection, 22(7), 1099-1106. https://doi.org/10.1016/S0261-2194(03)00143-1

Portal N, Soler A, Alphonsine P A M, Borras-Hidalgo O, Portieles R, Peña-Rodriguez L M, Yanes E, Herrera L, Solano J, Ribadeneira C, Walton J D. (2018). Nonspecific toxins as components of a host-specific culture filtrate from Fusarium oxysporum f. sp. cubense race 1. Plant Pathology, 67(2), 467476. https://doi.org/10.1111/ppa.12736

Pradeep T, Jambhale N D. (2002). Relationship between phenolics, polyphenol oxidase and peroxidases and resistance to powdery mildew in Zizhyphus. Indian Phytopathology, 55(2), 195-196.

Rahman M A, Begum M F, Alam M F. (2009). Screening of Trichoderma isolates as a biological control agent against Ceratocystis paradoxa causing pineapple disease of sugarcane. Mycobiology, 37(4), 277-285. https://doi.org/10.4489/ MYCO.2009.37.4.277

Ramdoss N. (1991). Studies on the epidemiology, pathophysiology and management of Thanjavur wilt of coconut (Doctoral dissertation, Tamil Nadu Agricultural University; Coimbatore).

Rashid, T. S., Sijam, K., Awla, H. K., Saud, H. M., \& Kadir, J. (2016). Pathogenicity assay and molecular identification of fungi and bacteria associated with diseases of tomato in Malaysia. American Journal of Plant Sciences, 7(6), 949-957. https://doi.org/10.4236/ajps.2016.76090

Silva R N, Monteiro V N, Steindorff A S, Gomes E V, Noronha E F, Ulhoa C J. (2019). Trichoderma/pathogen/plant interaction in pre-harvest food security. Fungal Biology, 123(8), 565583. https://doi.org/10.1016/j.funbio.2019.06.010

Sreedevi B, Devi M C, Saigopal D V R. (2011). Induction of defense enzymes in Trichoderma harzianum treated groundnut plants against Macrophomina phaseolina. Journal of Biological Control, 25(1), 33-39.

Verma M, Brar S K, Tyagi R D, Surampalli R Y, Valero J R. (2007). Antagonistic fungi, Trichoderma spp.: panoply of biological control. Biochemical Engineering Journal, 37(1), 1-20. https:// doi.org/10.1016/j.bej.2007.05.012

Vidhyasekaran P. (2004). Concise encyclopedia of plant pathology. CRC Press. https://doi.org/10.1201/9781482277951 